\title{
[RETRACTED ARTICLE] USE OF A SONOCATALYTIC PROCESS TO IMPROVE THE BIODEGRADABILITY OF LANDFILL LEACHATE
}

[RETRACTED ARTICLE] A. Roodbari, R. Nabizadeh Nodehi, A. H. Mahvi, S. Nasseri, M. H. Dehghani, and M. Alimohammadi, Use of a sonocatalytic process to improve the biodegradability of landfill leachate," Braz. J. Chem. Eng. vol. 29 no. 2 p. 221 - 230, São Paulo Apr./June 2012, http://dx.doi.org/10.1590/S0104-66322012000200003.

This article has been retracted because it contains substantial overlap in both text and technical content with two other publications of the same authors:

(1) Mahvi AH, Roodbari AA, Nabizadeh Nodehi R, Nasseri S, and Dehghani MH, Alimohammadi M. (2012), Improvement of landfill leachate biodegradability with ultrasonic process.

PLoS ONE 7(7): e27571.doi:10.1371/journal.pone.0027571,

(2) Mahvi Amirhossein, Roodbari Aliakbar, Nabizadeh Nodehi Ramin, Naseri Simin, Dehghani Mohammadhadii, and Alimohammadi Mahmood (2012) Improvement of Landfill Leachate Biodegradability with Ultrasonic Process. E-Journal of Chemistry, Volume 9 (2012), Issue 2, Pages 766-771. http://dx.doi.org/10.1155/2012/820971

Prof. Reinaldo Giudici

Editor-in-Chief, Brazilian Journal of Chemical Engineering 


\title{
Brazilian Journal \\ of Chemical \\ Engineering
}

\section{USE OF A SONOCATALYTIC PROCESS TQ IMPROVE THE BIODEGRADABILITY OF LANDFILL LEACHATE}

\author{
A. Roodbari ${ }^{1}$, R. Nabizadeh Nodehi ${ }^{1}$, A. H. Mahvi ${ }^{1,2,3^{*}}$, S. Nasc ri $^{1}$, M. N. Dehghani ${ }^{1}$ \\ and M. Alimohammadi ${ }^{1}$ \\ ${ }^{1}$ School of Public Health, Tehran University of Medical Scir aces, ', ehran, Iran. \\ E-mail: roodbari1@yahoo.com, rnabizadeh@tums.ac.ir, n. erise ctu ac.ir, \\ hdehghani@sina.tums.ac.ir,m_alimohammadi@tur.ac.ir \\ ${ }^{2}$ National Institute of Health Research, Tehran University o dical St nces, Tehran, Iran. \\ ${ }^{3}$ Center for Solid Waste Research, Institute for Environmental Researo Te University of Medical Sciences, \\ Phone: + 9821 88954914, Fax: + 9821 66462267, Enghelab Avenue chool of Public Health, Tehran, Iran. \\ *E-mail: ahmahvi@vahoo.com \\ (Submitted: July 24, 2011 ; Revised: Octo or 22, 201 ; Accepted: November 2, 2011)
}

\begin{abstract}
Landfill leachate is one of the mos impo ant su ces of toxic organic compounds for ground and surface waters. Advanced oxidation proces es n offer a effective and environmentally friendly method for pretreatment of landfill leachates. In this udy, an 1 tr? onic process was used for the pre-treatment of landfill leachate with the objective of impron.ng overalıoiodegradability, evaluated in terms of the $\mathrm{BOD}_{5} / \mathrm{COD}$ ratio, up to a value compatible with-1 iologica reatment. Under optimized experimental conditions ( $\mathrm{pH}$ of 10 , power of 110 watts, frequency $60 \mathrm{kHz} \mathrm{TiO}_{2}$ concentration of $5 \mathrm{mg} / \mathrm{L}$ and exposure time of $120 \mathrm{~min}$ ), this method showed suitability for $\mathrm{p}$ rtial rem val of chemical oxygen demand (COD). The biodegradability was significantly improved $\left(\mathrm{BOD}_{5} / \mathrm{CO}\right.$ incr sed from 0.210 to 0.786$)$ which allowed an almost total removal of COD by a sequential activ tem ${ }^{1}$ 11ge process.
\end{abstract}

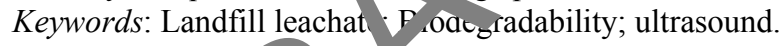

Leac'ate c nsists of many different organic and inorgani anpounds that may be either dissolved or su per. led ( il et al., 2005). These compounds pose pote $a$ pollution problem for local ground and su. "ce waters (Esplugas et al., 2004). Leachate from matu landfills is typically characterized by a high ammonium $\left(\mathrm{NH}_{4}^{+}\right)$content, low biodegradability (low $\mathrm{BOD}_{5} / \mathrm{COD}$ ratio) and a high fraction of refractory and large organic molecules such as humic and fulvic acids (Acgdacg and Sponza, 2005), but leachate from young landfills contains low organic compound concentrations (Li et al., 2010). Usually young landfill leachates are treated more easily as compared to the old one (Koh et al., 2004). Leachate is classified as stabilized (mature), intermediate, or fresh (young) given $\mathrm{BOD}_{5} / \mathrm{COD}$ values of $<0.2,0.2$ 0.5 , and $>0.5$, respectively (Robinson et al., 1983; Sun et al., 2010; Pilli et al., 2011). Some methods have been reported for the removal organics from landfill, such as biological treatment (aerobic, anaerobic and anoxic processes), physical methods (sedimentation, air stripping, adsorption, and membrane filtration) (Çeçen et al., 2003; Dehghani et al., 2007) and chemical methods (chemical precipitation (Lim et al., 2009; Kettunen et al., 1996), chemical oxidation (Zhao et al., 2010; Kurniawan et al., 2006), reverse osmosis, granular activated carbon (Peixoto et al., 2010), ion exchange

*To whom correspondence should be addressed 
resins and electrochemical oxidation (Bashir et al., 2010; Schuk et al., 1986)). In general, biological processes are preferred for the treatment of leachates with a high ratio of biochemical oxygen demand to chemical oxygen demand $\left(\mathrm{BOD}_{\mathrm{U}} / \mathrm{COD}\right)$ (Peixoto et al., 2009) and of fresh leachates containing mainly volatile fatty acids (Abdul Aziz et al., 2011). Compact physical and chemical methods have been suggested for the treatment of old, stabilized and dilute leachates with low biodegradability (Kurniawan et al., 2004; Kargi et al., 2004). Because of the variation in leachate composition and the wide range of pollutants contained in leachate, it is difficult to predict a treatment technique that will be effective for leachate (Atmaca, 2009; Mahvi, 2009). Usually a combination of physical, chemical and biological methods is used for effective treatment of landfill leachate, since it is difficult to obtain satisfactory results by using any one of those methods alone (Kurniawan et al., 2004). Traditionally, the degradation of organic compounds can be achieved by advanced oxidation processes (AOPs) (Anglada et al., 2011; Kargi et al., 2003). AOPs have been used to enhance the biotreatability of liquids containing various organic compounds that are non-biodegradable and/or toxic to common microorganisms (Chiang et al., 1995; Cortez et l., 2011). The ultrasonic process is one of AOP and involves pyrolysis phenomena (thermal deg datio and the generation of the hydroxyl $\mathrm{rad}^{\mathrm{a}} \mathrm{(}(\cdot \mathrm{OH})$, which has a very high oxidation potential and able to oxidize almost all organic pollu unts and volatile matter such as $\mathrm{NH}_{3}$ (Mahvi et al., 2009). I lthough this process is very effective for omplete mineralization of pollutants, it $\mathrm{r}$ is applied as the only treatment process it "Al be expensive. However, if the ultra onic proc s is used as a pretreatment with otho $m$ no such as biological processes, its y can optimized and be more useful for le cha treatment (Ben Yahmed et al., 2009; Lim et al., 20 0). The objective of this study was to ivesti ate the effect of the ultrasonic process as a pr eatm it for leachate biodegradability in pro emen.

\section{MATERIALS AND METHODS}

\section{Materials}

Samples of landfill leachate were obtained from a municipal landfill site (over 10 years old) located in Shahrood (Semnan, Iran). All leachate samples were collected from leachate lift stations or storage tanks, stored at $3^{\circ} \mathrm{C}$, and tested within 2 days of collecting the samples. The main chemical characteristics of the raw leachate are summarized in Table 1. The ammonium concentrations were analyzed with a $\mathrm{C}_{203} 8$ parameter test meter (Hanna Electronics Co., Ltd.). The $\mathrm{pH}$ was measured by a Benchtop $\mathrm{pH}$ Meter (Cole-Parmer Co., Ltd). The $\mathrm{pH}$ meter was calibrated before each use with $\mathrm{pH} 3,7$ and 10 buffer st tutions. BOD and COD measurements were eterm ned following Standard Methods 5210 a 5220 respectively. Reagents and standard chemica v re purchased from Hach Co., except for he BOD buffer solution, which was prepared ccording to standard Method 5210. Ferrous su phate $\mathrm{FeSO}_{4} \cdot 7 \mathrm{H}_{2} \mathrm{O}$ ), sulphuric acid and hydrogen, ner, ide (M rck, $30 \mathrm{wt}$ \%) were of analytical gra e. BO chuc standards were performed with ea $A$ tch of $\mathrm{ODD}$ measurements. The results were conside d good when the value of the BOD ch $\mathrm{ck} \mathrm{s}$ andard rell within the range of $198 \pm 30.5 \mathrm{~m}, \mathrm{~L} \quad$ Th qverage \pm standard deviation of the POD ch $\mathrm{k}$ standards for the entire duration of the pr iect was $169 \pm 29.0 \mathrm{mg} / \mathrm{L}$, which demonstr to good results given the inherent variability in BOD measurements. COD check sta dards were also performed with each batch of COD measurements. A COD standard solution of $100 / \mathrm{mg} / \mathrm{L}$ was diluted to 200 and $500 \mathrm{mg} / \mathrm{L}$ to ensure the accuracy of COD measurements. The relative difference for calibration check standards $\left(\mathrm{RD}_{\text {cal }}\right)$ is defined as the absolute difference of the check standard concentration and the known concentration all divided by the known concentration. The $\mathrm{RD}_{\text {cal }}$ for COD was $<10 \%$ for the entire duration of the project.

\section{Experimental Set-Up}

As shown in Figure 1, for the laboratory experiments a cylindrical shaped Plexiglas reactor with total volume of $1 \mathrm{~L}$ was prepared. The solution in the reactor was mixed with a magnetic stirrer, while sufficient aeration was provided by a compressor connected to a porous stone located in the bottom of the reactor. The compressor was used to ensure a completely mixed condition in the reactor. The ultrasonic source was a Model UGMA-5000 ultrasound generator with three $(30,45$ and $60 \mathrm{kHz})$ transducers having a titanium probe with $20 \mathrm{~mm}$ diameter. The power input could be adjusted continuously from 60 to $120 \mathrm{~W}$. A leachate sample of $1000 \mathrm{ml}$ was sonicated in a covered cylindrical glass vessel. Aeration was supplied by a Model SALWAT air compressor. The sludge was continuously aerated using aeration pumps. 


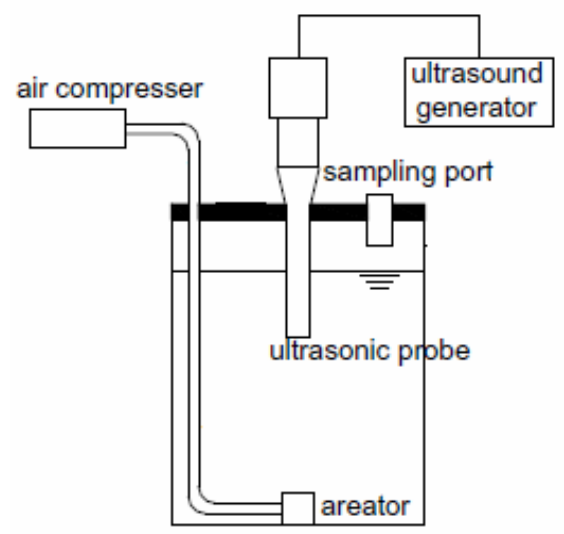

Figure 1: Schematic diagram of the reactor

\section{Procedure}

After the optimization by factorial design, the ultrasonic irradiation was applied in the treatment of raw leachates using a batch mode. At first, the raw leachate sample was filtered through filter paper $(0.45 \mu)$ to remove any suspended solid impurity. Then the sample was adjusted to the required $\mathrm{pH}$ with $\mathrm{H}_{2} \mathrm{SO}_{4}$ or $\mathrm{NaOH}$. Then different scenarios were tested with regard to power intensities of 70 and $110 \mathrm{~W}$, frequencies of 30,45 and $60 \mathrm{kHz}$, reaction times $30,60,90$ and 120 minutes and $\mathrm{pH}$ of 3, 7 and 10 . For determining the effect of catalyst on sor ica efficiency, $5 \mathrm{mg} / \mathrm{L}$ of $\mathrm{TiO}_{2}$ and $\mathrm{ZnO}$ have en use separately. To evaluate the effect or ult sonic irradiation on the biodegradabilit $O$ raw nd sonochemically pre-treated leach tes, $\mathrm{BCD}_{5}$ and COD of both samples were measure

\section{Biological Procedure}

The activated Idge ten was applied in cylindrical aerat on s s-vessels $(30 \mathrm{~cm}$ internal diameter and $0 \mathrm{~cm}$ in height). The system was aerated by sising a pumps placed at the bottom of the react rs. The initul volume of the culture was $150 \mathrm{~m}$ v aich was completed to $300 \mathrm{~mL}$ with

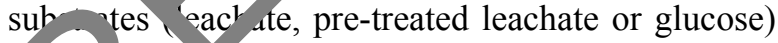
the regining of each cycle. The $\mathrm{pH}$ was co olled oy a probe and adjusted to 7.0 by using $\mathrm{H}_{2} \mathrm{Su}$ or $\mathrm{NaOH}$. The oxygen concentration was monitored by using an $\mathrm{O}_{2}$ probe, located at the top of the reactor. All the experiments were carried out in duplicate and at room temperature $\left(20-25^{\circ} \mathrm{C}\right)$ for periods of $72 \mathrm{~h}$. For COD determinations, samples $(10 \mathrm{ml}$ each) were taken every $12 \mathrm{~h}$, after they had been centrifuged and filtered through a $0.45 \mathrm{~mm}$ Millipore filter (De Morais and Zamora, 2005).

\section{RESULTS AND DISCUSSION}

\section{Characterization of the Raw Landfill Leachate}

The main chemical characteristics of raw leachate are summarized in Table 1 . When the biodegradability ratio $\left(\mathrm{BOD}_{5} / \mathrm{COD}\right)$ is lower than 0.25 and the $\mathrm{pH}$ near to 8 , the samples can be considered to be mo Aerately stabilized leachates (Wang et al., 2009' In tost cases, intensive and sophisticated physio ${ }^{\prime}$ mica processes are necessary for the treatment of are leachates.

Table 1: Chemical charact ristics of the studied landfill leachates

\begin{tabular}{|l|r|l|r|}
\hline \multicolumn{2}{|c|}{ Parameters Value } & \multicolumn{2}{c|}{ P. ameters Values } \\
\hline $\mathrm{COD}$ & $56^{\mathrm{O} 1}-83$ & $\mathrm{U}$ & $7.9-8.1$ \\
$\mathrm{Calcium}$ & $.61 \pm 0$ & Magnesium & 8.65 \\
$\mathrm{BOD}_{\mathrm{u}}$ & $73-36$ & $\mathrm{NH}_{3}-\mathrm{N}$ & $726 \pm 25$ \\
$\mathrm{BOD}_{5}$ & $1-6.6$ & $\mathrm{Alkalinity}$ as $\mathrm{CaCO}_{3}$ & $3650 \pm 123$ \\
$\mathrm{TOC}^{2}$ & $26 \pm 20$ & $\mathrm{TS}$ & $1420 \pm 29$ \\
$\mathrm{BOD}_{5} / \mathrm{CO}$ & 0.21 & & \\
\hline
\end{tabular}

Values (ex,, $\mathrm{pt} \mathrm{pH})$ in $\mathrm{mg} / 1$

Effe $t$ of the Sonocatalytic Process on the i degradability of Leachate

The results indicated that the sonocatalytic process can improve leachate biodegradability $\left(\mathrm{BOD}_{5} / \mathrm{COD}\right.$ ratio). The $\mathrm{BOD}_{5} / \mathrm{COD}$ ratio for raw leachate was 0.210 , but it reached 0.786 (with $\mathrm{TiO}_{2}$ ) and 0.783 (with $\mathrm{ZnO}$ ) after sonication. Independent Samples T-test showed that there is significant difference between the $\mathrm{BOD}_{5} / \mathrm{COD}$ ratios of raw leachate and pretreated leachate with the sonocatalytic process ( $p_{\text {value }}=0.000$ for both $\mathrm{TiO}_{2}$ and $\mathrm{ZnO}$ ). The results indicated that the system operates with great efficiency $\left(\mathrm{BOD}_{5} / \mathrm{COD}\right.$ ratio $\left.=0.786\right)$ at $\mathrm{pH} 10$, power of 110 watts, frequency of $60 \mathrm{kHz}$ and $\mathrm{TiO}_{2}$ concentration of $5 \mathrm{mg} / \mathrm{L}$.

\section{Effect of the Ultrasound Power Input on Biodegradability Improvement}

Figure 2 shows the effect of power input on leachate biodegradability for $\mathrm{TiO}_{2}$ and $\mathrm{ZnO}$. As shown in this figure, the power input clearly improves biodegradability. Independent Samples T-test (Table 2) showed that there is a significant difference between the $\mathrm{BOD}_{5} / \mathrm{COD}$ ratios of raw leachate and pretreated leachate at different powers. $\left(\mathrm{p}_{\text {value }}=0.000\right.$ for both $\mathrm{TiO}_{2}$ and $\left.\mathrm{ZnO}\right)$. 


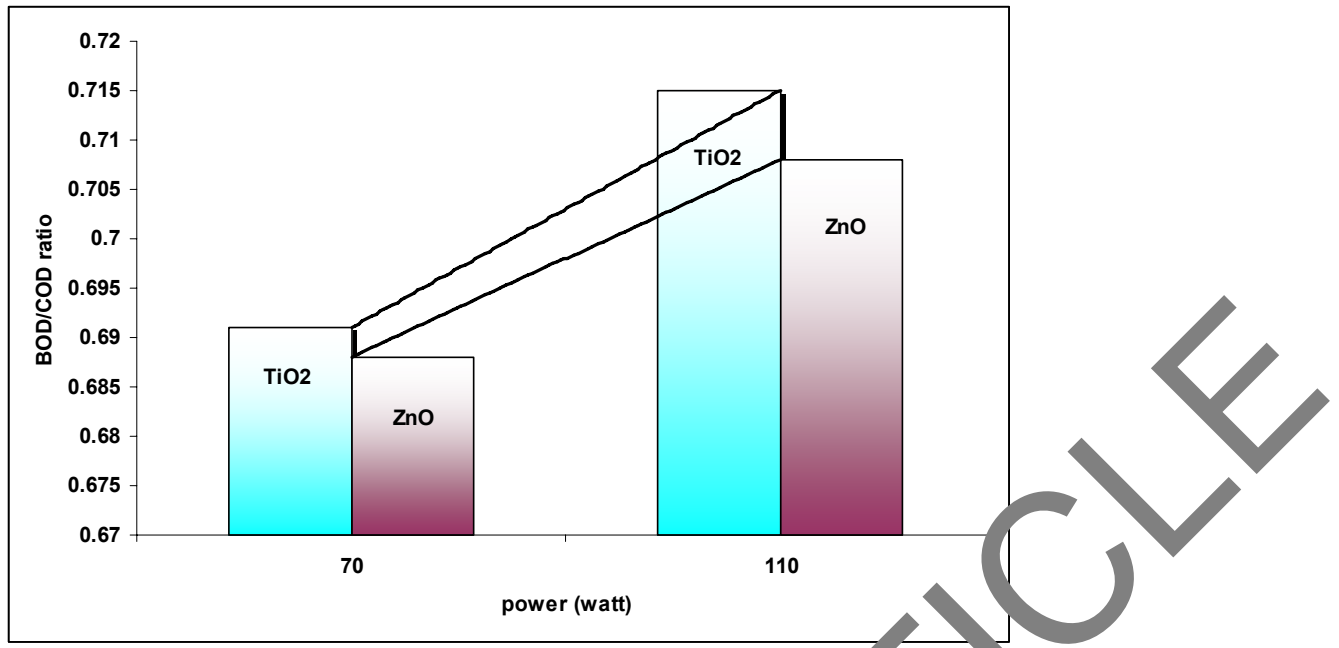

Figure 2: $\mathrm{BOD}_{5} / \mathrm{COD}$ ratios for $\mathrm{TiO}_{2}$ and $\mathrm{ZnO}$ at diff $\mathrm{tt}$ powe. inputs (Frequency $=30 \mathrm{kHz}$, concentration $=5 \mathrm{mg} / \mathrm{L}, \mathrm{pH}=3$ )

Table 2: Results of Independent Samples Test or p ro inputs

\begin{tabular}{|c|c|c|c|c|c|c|c|c|c|c|}
\hline & \multicolumn{2}{|c|}{$\begin{array}{c}\text { Levene's Test for } \\
\text { Equality of Variances }\end{array}$} & \multirow{3}{*}{$\mathbf{t}$} & \multirow{3}{*}{ dt } & \multirow{3}{*}{$\begin{array}{l}\text { Sig. } \\
\text { 2-tailed }\end{array}$} & \multirow{3}{*}{$\begin{array}{c}\text { Mean } \\
\text { Difference }\end{array}$} & \multirow{3}{*}{$\begin{array}{l}\text { Std. Error } \\
\text { Difference }\end{array}$} & \multirow{2}{*}{\multicolumn{2}{|c|}{\begin{tabular}{|c|}
$95 \%$ Confidence \\
Interval of the Difference
\end{tabular}}} \\
\hline & & \multirow[t]{2}{*}{$\mathbf{F}$} & \multirow[t]{2}{*}{ Sig. } & & & & & & & \\
\hline & & & & & & & & & Lower & Upper \\
\hline \multirow{2}{*}{$\begin{array}{l}\text { PERCENT of } \\
\text { reduction with } \\
\mathrm{TiO}_{2}\end{array}$} & $\begin{array}{l}\text { Equal variances } \\
\text { assumed }\end{array}$ & 41.3 & 0.000 & & & 0.000 & -0.043361 & 0.004058 & -0.051454 & -0.035268 \\
\hline & \begin{tabular}{|l} 
Equal variances \\
not assumed \\
\end{tabular} & & & & & 0.000 & -0.043361 & 0.004058 & -0.051523 & -0.35199 \\
\hline \multirow{2}{*}{$\begin{array}{l}\text { PERCENT of } \\
\text { reduction with } \\
\mathrm{ZnO}\end{array}$} & $\begin{array}{l}\begin{array}{l}\text { Equal variances } \\
\text { assumed }\end{array} \\
\end{array}$ & 28.5 & & & & 0.000 & -0.038556 & 0.004020 & -0.046573 & -0.030538 \\
\hline & $\begin{array}{l}\text { Equal variances } \\
\text { not assumed }\end{array}$ & & & & 4.77 & 0.000 & -0.038556 & 0.004020 & -0.046643 & -0.30538 \\
\hline
\end{tabular}

According to sonochemistry th ory, $y$ len the ultrasound intensity reaches o vceeas cavitation threshold, bubbles will be $\mathrm{t} \mathrm{rm}$ - ansily and the cavities collapse violer $2 \mathrm{y}$ Inci asing the ultrasonic power will increase e ene of avitation, lowering the threshold lim or vitation, and enhancing the quantity of ca ation bu bles (Kurniawan and Lo, 2009). In other ords, at higher intensities, the concentr ion of hydi xyl radicals and mass transfer are hig er, which leads to more degradation of org ma rial chianese et al., 1999) and also more 1 odeg adablo intermediate compounds. The e. " oncy of ratio improvement then increases with the $\mathrm{h}$ rease of ultrasonic intensity.

\section{Effect of Exposure Time on Biodegradability Improvement}

Results indicated that the exposure time somehow improved biodegradability. Figure 3 shows the effect of exposure time on leachate biodegradability for
$\mathrm{TiO}_{2}$ and $\mathrm{ZnO}$. A One-Way ANOVA test (Table 3) showed that there is no significant difference between the $\mathrm{BOD}_{5} / \mathrm{COD}$ ratios of raw leachate and pretreated leachate with sonocatalytic process at different exposure times $\left(\mathrm{p}_{\text {value }}=0.467\right.$ for $\mathrm{TiO}_{2}$ and 0.398 for $\left.\mathrm{ZnO}\right)$.

\section{Effect of Frequency on Biodegradability Improvement}

Results indicated that the frequency clearly improve biodegradability. Figure 4 shows the effect of frequency on leachate biodegradability for $\mathrm{TiO}_{2}$ and $\mathrm{ZnO}$. A One-Way Anova test (Table 4) showed that there is significant difference between the $\mathrm{BOD}_{5} / \mathrm{COD}$ ratios of raw leachate and pretreated leachate with the sonocatalytic process at different frequencies $\left(p_{\text {value }}=0.000\right.$ for both $\mathrm{TiO}_{2}$ and $\left.\mathrm{ZnO}\right)$. Results of the Tukey statistical test (Table 5) also showed that there are significant differences between frequencies of 30 and $60 \mathrm{kHz}\left(\mathrm{p}_{\text {value }}=0.000\right)$ and between 45 and $60 \mathrm{kHz}\left(\mathrm{p}_{\text {value }}=0.000\right)$. 


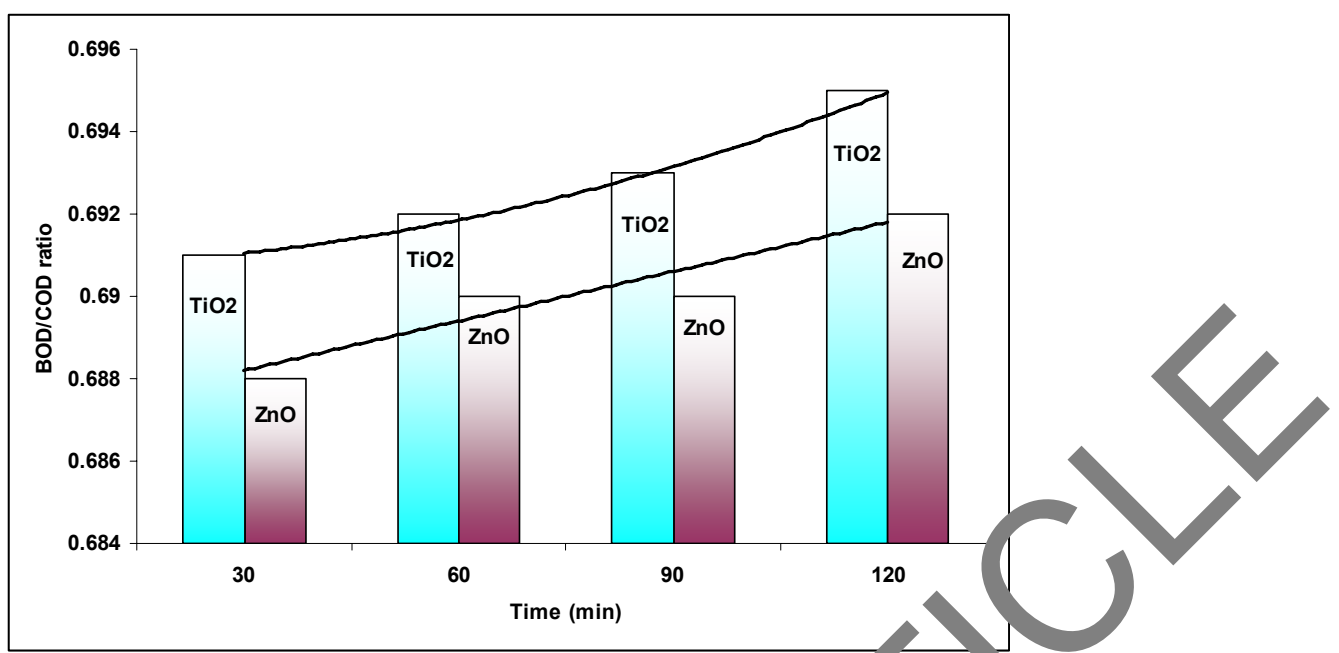

Figure 3: $\mathrm{BOD}_{5} / \mathrm{COD}$ ratios for $\mathrm{TiO}_{2}$ and $\mathrm{ZnO}$ at differe 4 exposur times (Frequency $=30 \mathrm{kHz}$, concentration $=5 \mathrm{mg} / \mathrm{L}, \mathrm{pH}=3$ )

Table 3: Results of One-Way ANOVA test for difi cent xp sure times

\begin{tabular}{|c|c|c|c|c|c|c|c|c|c|c|}
\hline & \multicolumn{2}{|c|}{ Sum of Squares } & \multicolumn{2}{|c|}{ df } & \multicolumn{2}{|c|}{ Mean Sq } & \multicolumn{2}{|c|}{$\mathbf{F}$} & \multicolumn{2}{|c|}{ Sgi } \\
\hline & $\begin{array}{l}\text { With } \\
\mathrm{TiO}_{2}\end{array}$ & $\begin{array}{l}\text { With } \\
\text { ZnO }\end{array}$ & $\begin{array}{l}\text { With } \\
\text { TiO }_{2}\end{array}$ & $\begin{array}{l}\text { With } \\
\text { ZnO }\end{array}$ & $\begin{array}{l}\text { With } \\
\mathrm{TiO}_{2}\end{array}$ & & $\begin{array}{l}\text { With } \\
\mathrm{TiO}_{2}\end{array}$ & $\begin{array}{l}\text { With } \\
\text { ZnO }\end{array}$ & $\begin{array}{l}\text { With } \\
\text { TiO }_{2}\end{array}$ & $\begin{array}{l}\text { With } \\
\text { ZnO }\end{array}$ \\
\hline Between Groups & 0.002 & 0.002 & 3 & 3 & $0 \times n+1$ & $\overline{0.0}$ & 1.00 & 0.859 & 0.398 & 0.467 \\
\hline Within Groups & 0.052 & 0.045 & 68 & 68 & & 0.001 & & & & \\
\hline Total & 0.055 & 0.047 & 71 & 71 & & & & & & \\
\hline
\end{tabular}

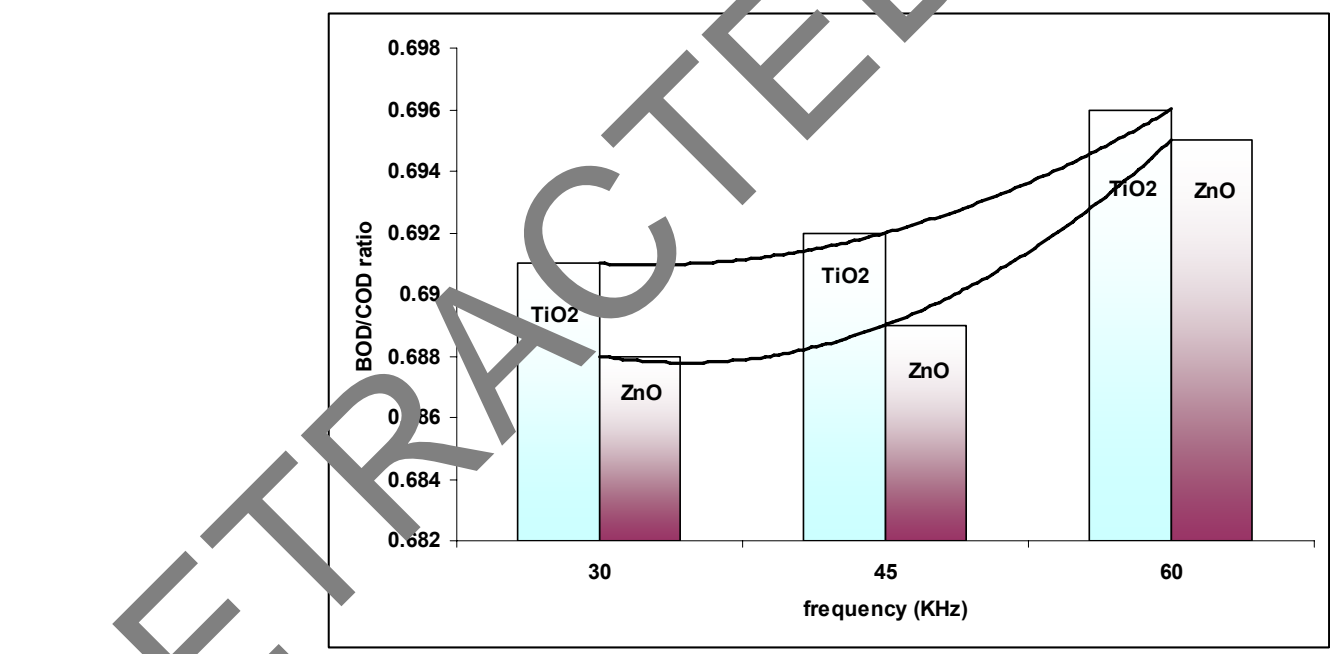

Figure 4: $\mathrm{BOD}_{5} / \mathrm{COD}$ ratios for $\mathrm{TiO}_{2}$ and $\mathrm{ZnO}$ at different frequencies (power $=70$ watt, concentration $=5 \mathrm{mg} / \mathrm{L}, \mathrm{pH}=3$ )

Table 4: Results of One-Way ANOVA test for different frequencies

\begin{tabular}{|c|c|c|c|c|c|c|c|c|c|c|}
\hline & \multicolumn{2}{|c|}{ Sum of Squares } & \multicolumn{2}{|c|}{ df } & \multicolumn{2}{|c|}{ Mean Square } & \multicolumn{2}{|c|}{$\mathbf{F}$} & \multicolumn{2}{|c|}{ Sgi } \\
\hline & $\begin{array}{l}\text { With } \\
\mathrm{TiO}_{2}\end{array}$ & $\begin{array}{l}\text { With } \\
\text { ZnO }\end{array}$ & $\begin{array}{l}\text { With } \\
\mathrm{TiO}_{2}\end{array}$ & $\begin{array}{l}\text { With } \\
\text { ZnO }\end{array}$ & $\begin{array}{l}\text { With } \\
\mathrm{TiO}_{2}\end{array}$ & $\begin{array}{l}\text { With } \\
\text { ZnO }\end{array}$ & $\begin{array}{l}\text { With } \\
\mathrm{TiO}_{2}\end{array}$ & $\begin{array}{l}\text { With } \\
\text { ZnO }\end{array}$ & $\begin{array}{l}\text { With } \\
\mathrm{TiO}_{2}\end{array}$ & $\begin{array}{l}\text { With } \\
\text { ZnO }\end{array}$ \\
\hline Between Groups & 0.013 & 0.012 & 2 & 2 & 0.006 & 0.006 & 10.718 & 11.818 & 0.000 & 0.000 \\
\hline Within Groups & 0.042 & 0.035 & 69 & 69 & 0.001 & 0.001 & & & & \\
\hline Total & 0.055 & 0.047 & 71 & 71 & & & & & & \\
\hline
\end{tabular}


Table 5: Results of Tukey test for different frequencies

\begin{tabular}{|c|c|c|c|c|c|c|c|c|c|c|c|}
\hline \multirow{3}{*}{$\begin{array}{c}\text { (I) } \\
\text { frequency }\end{array}$} & \multirow{3}{*}{$\begin{array}{c}(\mathbf{J}) \\
\text { frequency }\end{array}$} & \multicolumn{2}{|c|}{ Mean Difference (I-J) } & \multicolumn{2}{|c|}{ Std. Error } & \multicolumn{2}{|c|}{ Sig. } & \multicolumn{4}{|c|}{ 95\% Confidence Interval } \\
\hline & & \multirow[b]{2}{*}{$\begin{array}{l}\text { With } \\
\mathrm{TiO}_{2}\end{array}$} & \multirow[b]{2}{*}{$\begin{array}{l}\text { With } \\
\text { ZnO }\end{array}$} & \multirow[b]{2}{*}{$\begin{array}{l}\text { With } \\
\mathrm{TiO}_{2}\end{array}$} & \multirow[b]{2}{*}{$\begin{array}{l}\text { With } \\
\text { ZnO }\end{array}$} & \multirow[b]{2}{*}{$\begin{array}{l}\text { With } \\
\mathrm{TiO}_{2}\end{array}$} & \multirow[b]{2}{*}{$\begin{array}{l}\text { With } \\
\text { ZnO }\end{array}$} & \multicolumn{2}{|c|}{ Lower Bound } & \multicolumn{2}{|c|}{ Upper Bound } \\
\hline & & & & & & & & $\begin{array}{l}\text { With } \\
\mathrm{TiO}_{2}\end{array}$ & $\begin{array}{l}\text { With } \\
\text { ZnO }\end{array}$ & $\begin{array}{l}\text { With } \\
\mathrm{TiO}_{2}\end{array}$ & $\begin{array}{l}\text { With } \\
\text { ZnO }\end{array}$ \\
\hline \multirow{2}{*}{30} & 45 & -0.0112 & -0.0095 & 0.007 & .0060 & 0.261 & 0.311 & -0.028 & -0.025 & 0.005 & 0.006 \\
\hline & 60 & -0.0323 & -0.0309 & 0.007 & 0.006 & 0.000 & 0.000 & -0.049 & -0.046 & -0.015 & -0.015 \\
\hline \multirow{2}{*}{45} & 30 & 0.01120 & 0.00958 & 0.007 & 0.006 & 0.261 & 0.311 & -0.005 & -0.006 & 0.028 & 9.025 \\
\hline & 60 & -0.0211 & -0.0213 & 0.007 & 0.006 & 0.011 & 0.005 & -0.038 & -0.036 & -0.004 & -0.005 \\
\hline \multirow{2}{*}{60} & \multirow{2}{*}{30} & 0.0323 & 0.03091 & 0.007 & 0.006 & 0.000 & 0.000 & 0.015 & 0.015 & $0.04 \mathrm{C}$ & $0,4 \overline{6}$ \\
\hline & & 0.0211 & 0.02133 & 0.007 & 0.006 & 0.011 & 0.005 & 0.004 & 0.005 & 0.038 & 036 \\
\hline
\end{tabular}

\section{Effect of pH on Biodegradability Improvement}

Results indicated that the $\mathrm{pH}$ somehow improves biodegradability. Figure 5 shows the effect of $\mathrm{pH}$ on leachate biodegradability for $\mathrm{TiO}_{2}$ and $\mathrm{ZnO}$. A OneWay ANOVA test (Table 6) showed that there is no significant difference between the $\mathrm{BOD}_{5} / \mathrm{COD}$ ratios of raw leachate and pretreated leachate with the sonocatalytic process at different $\mathrm{pHs}\left(\mathrm{p}_{\text {value }}=0.503\right.$ for $\mathrm{TiO}_{2}$ and 0.170 for $\mathrm{ZnO}$ ).

\section{Effect of Type of Catalyst on Biodegradability Improvement by Ultrasound}

Figure 6 shows the effect of the type of catalyst on the leachate biodegradability $\left(\mathrm{BOD}_{5} / \mathrm{COD}\right.$ ratic . on leachate biodegradability were milar but an Independent Samples T-test ( $\mathrm{able} 7$ ) in $\mathrm{di}$ ated that there is no significant di ference between the $\mathrm{BOD}_{5} / \mathrm{COD}$ ratios of ra le hate ho pretreated leachate with $\mathrm{TiO}_{2}$ an $r^{\prime} \mathrm{LnO}$ (value - v.287).

Concurrent Effect f Power Input and Frequency o Bit degradability Improvement by Ultrasound

As 1 in ined bove, power and frequency were effective $\mathfrak{p}$ ian.ters (statistically significant) for biodegrad bility improvement by the sonocatalytic pr cess. The Univariate statistic test (Table 8) shov d that estimates of the size of the effect were $88.6 \%$ for power and $74.9 \%$ for frequency but the current effect was smaller (44.4\%).

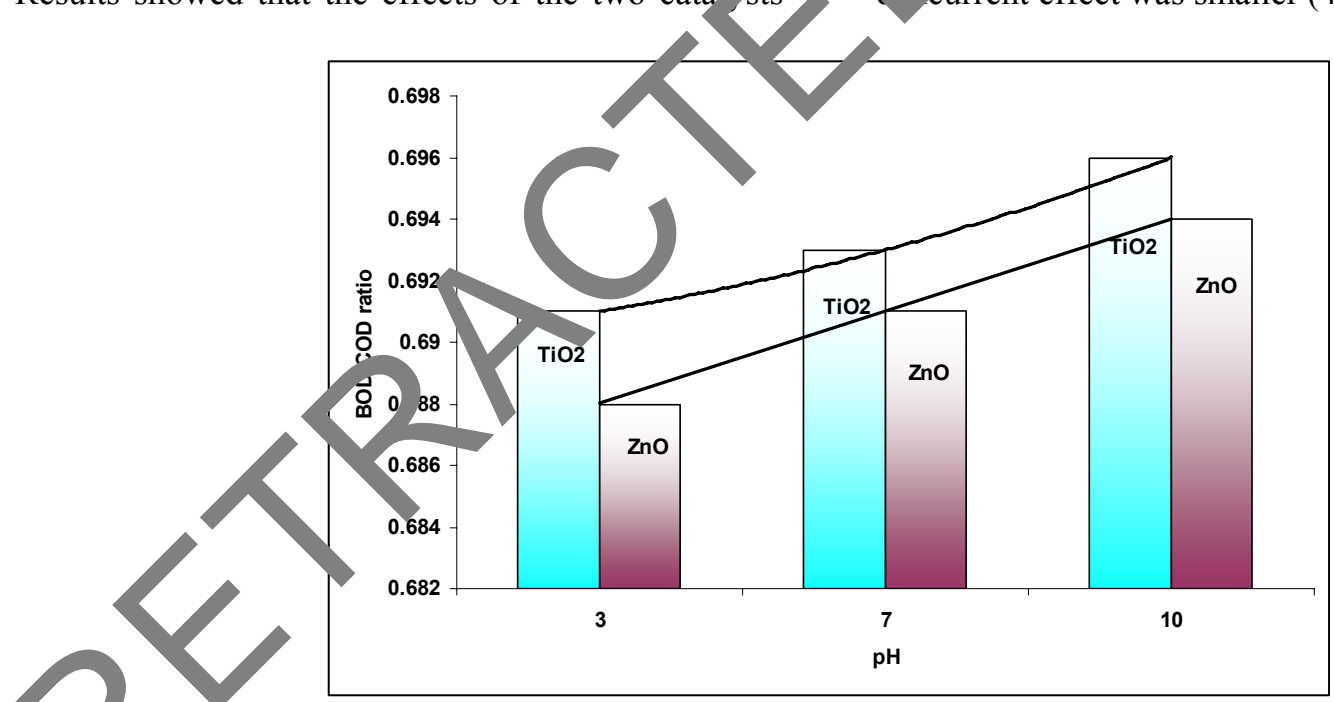

Figure 5: $\mathrm{BOD}_{5} / \mathrm{COD}$ ratios for $\mathrm{TiO}_{2}$ and $\mathrm{ZnO}$ at different $\mathrm{pH}_{\mathrm{S}}$ (power $=70$ watt, concentration $=5 \mathrm{mg} / \mathrm{L}$, frequency $=30 \mathrm{kHz}$ )

Table 6: Results of One-Way ANOVA test for different PHs

\begin{tabular}{|c|c|c|c|c|c|c|c|c|c|c|}
\hline & \multicolumn{2}{|c|}{ Sum of Squares } & \multicolumn{2}{|c|}{ df } & \multicolumn{2}{|c|}{ Mean Square } & \multicolumn{2}{|c|}{$\mathbf{F}$} & \multicolumn{2}{|c|}{ Sgi } \\
\hline & $\begin{array}{l}\text { With } \\
\mathrm{TiO}_{2}\end{array}$ & $\begin{array}{l}\text { With } \\
\text { ZnO }\end{array}$ & $\begin{array}{l}\text { With } \\
\mathrm{TiO}_{2}\end{array}$ & $\begin{array}{l}\text { With } \\
\text { ZnO }\end{array}$ & $\begin{array}{l}\text { With } \\
\mathrm{TiO}_{2}\end{array}$ & $\begin{array}{l}\text { With } \\
\text { ZnO }\end{array}$ & $\begin{array}{l}\text { With } \\
\mathrm{TiO}_{2}\end{array}$ & $\begin{array}{l}\text { With } \\
\text { ZnO }\end{array}$ & $\begin{array}{l}\text { With } \\
\mathrm{TiO}_{2}\end{array}$ & $\begin{array}{l}\text { With } \\
\text { ZnO }\end{array}$ \\
\hline Between Groups & 0.001 & 0.020 & 2 & 2 & 0.001 & 0.001 & 0.693 & 1.821 & 0.503 & 0.170 \\
\hline Within Groups & 0.054 & 0.045 & 69 & 69 & 0.001 & 0.001 & & & & \\
\hline Total & 0.055 & 0.047 & 71 & 71 & & & & & & \\
\hline
\end{tabular}




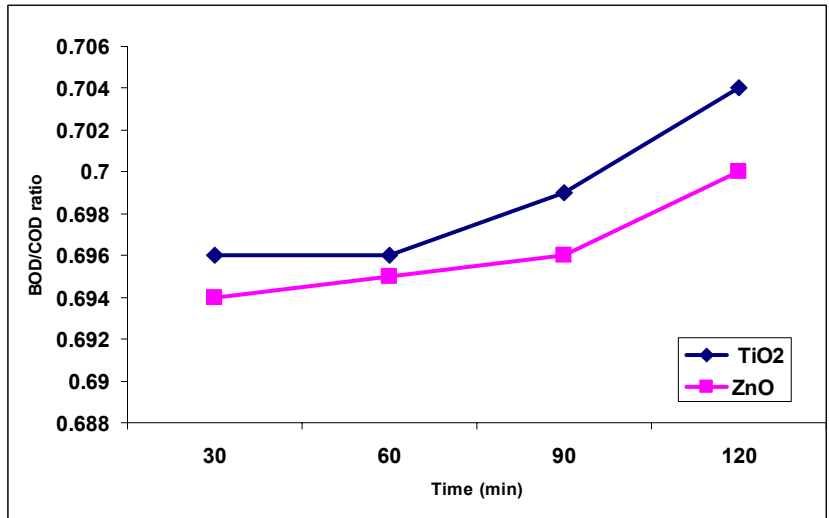

Figure 6: $\mathrm{BOD}_{5} / \mathrm{COD}$ ratios for $\mathrm{TiO}_{2}$ and $\mathrm{ZnO}$ (power $=70$ watt, concentration $=5 \mathrm{mg} / \mathrm{L}$, frequency $=30 \mathrm{kHz}$ )

Table 7: Results of Independent Samples Test for two a talysts

\begin{tabular}{|c|c|c|c|c|c|c|c|c|c|c|}
\hline & \multicolumn{2}{|c|}{\begin{tabular}{|l|l|} 
Levene's Test for \\
Equalityof Variances \\
\end{tabular}} & \multicolumn{7}{|c|}{ t-test fo cqu lity of Muans } \\
\hline & & \multirow[t]{2}{*}{$\mathbf{F}$} & \multirow[t]{2}{*}{ Sig. } & \multirow[t]{2}{*}{$\mathbf{t}$} & \multirow[t]{2}{*}{ df } & \multirow[t]{2}{*}{$\begin{array}{c}\text { Sig. } \\
\text { (2-tailed) }\end{array}$} & \multirow[t]{2}{*}{$\begin{array}{c}\text { an } \\
\text { Differ ce }\end{array}$} & \multirow[t]{2}{*}{$\begin{array}{l}\text { St } \text { Error } \\
\text { Difference }\end{array}$} & \multicolumn{2}{|c|}{$\begin{array}{c}\text { 95\% Confidence Interva } \\
\text { of the Difference }\end{array}$} \\
\hline & & & & & & & & & Lower & Upper \\
\hline \multirow{2}{*}{$\begin{array}{l}\text { PERCENT } \\
\text { of reduction }\end{array}$} & $\begin{array}{l}\text { Equal variances } \\
\text { assumed }\end{array}$ & 0.571 & 0.451 & 1.068 & 142 & 0.287 & & 0.00446 & -0.00405 & -0.01358 \\
\hline & $\begin{array}{l}\text { Equal variances } \\
\text { not assumed }\end{array}$ & & & 1.068 & & & 476 & 0.00446 & -0.00405 & -0.01358 \\
\hline
\end{tabular}

Table 8: Results of Univariate statistic test fo cor urrent effect of power and frequency

\begin{tabular}{|l|c|c|c|c|c|c|}
\hline \multicolumn{1}{|c|}{ Source } & $\begin{array}{c}\text { Type III } \\
\text { Sum of Squares }\end{array}$ & dt & Aean Square & F & Sig. & $\begin{array}{c}\text { Partial Eta } \\
\text { Squared }\end{array}$ \\
\hline Corrected Model & 0.050 & 5 & 0.010 & 152.896 & 0.000 & 0.921 \\
Intercept & 37.673 & & 37.673 & $5.731 \mathrm{E} 5$ & 0.000 & 1.000 \\
POWER & $0.0+4$ & 1 & 0.034 & 514.876 & 0.000 & 0.886 \\
FREQUENCY & $0 .(3$ & 2 & 0.006 & 98.421 & 0.000 & 0.749 \\
POWER * FREQUENCY & 0.0 & 2 & 0.002 & 26.380 & 0.000 & 0.444 \\
Error & 0.004 & 66 & 6.573 & & & \\
Total & 37 & 72 & & & & \\
Corrected Total & 37 & 71 & & & & \\
\hline
\end{tabular}

Biodegradability ha ges During Ultrasonic Decomposition

Initiall the bion radability of the leachates was evaluat 1 thre agh the evolution of the $\mathrm{BOD}_{5} / \mathrm{COD}$ ratio. For areate samples, this parameter has values of abo t 0.2 . nile ultrasonic treatment for $120 \mathrm{~min}$ ermit enhancement up to values near 0.786, Wh in represents substantial biodegradability accor ing to the current literature (Bae et al., 1999; Pi et al., 2009). This result indicates that the ultrasonic process can break down or rearrange molecular structures of organic matter and convert the nonbiodegradable organics to more biodegradable forms. This is a fact of remarkable importance in the case of the application of an integrated chemical-biological system to leachate treatment (De Morais and Zamora, 2005). In general, it is admitted that an ultrasonic process can transform recalcitrant organic compounds into easily biodegradable products, improving the efficiency and reducing the cost of further biological steps. In a second phase, raw and pre-treated leachate was submitted to a biological degradation process using a sequential batch reactor. The evolution of the COD during the biological treatment (Figure 7) confirms the low biodegradability of raw leachates, which achieve a maximal COD removal of about $30 \%$ at $72 \mathrm{~h}$ of treatment. On the other hand, the COD of pre-treated leachates decreases progressively, attaining COD removal higher than $90 \%$ at the end of the $72-h$ cycle. Additionally, the use of ultrasonically pretreated samples favored the preservation of the physical characteristics of the biological sludge, which could be corroborated by the measurement of traditional physical parameters and microscopic observation. 


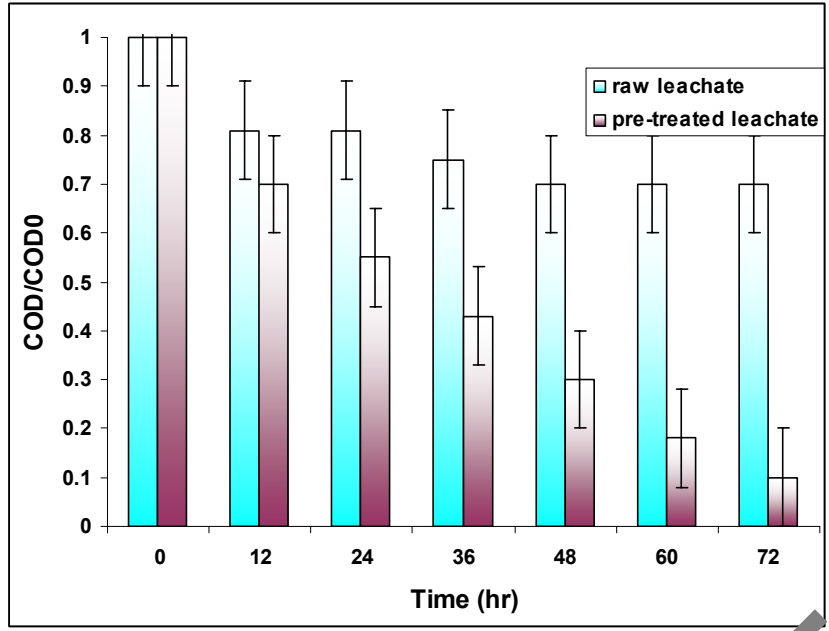

Figure 7: Evolution of the COD during biological treatme of the leachates (sample pretreated with a power of 110 watts, frequ ncy of $60 \mathrm{kHz}, \mathrm{pH}$ of 7 and $5 \mathrm{mg} / \mathrm{L}$ of $\mathrm{TiO}_{2}$ for $120 \mathrm{minu}^{+}$oر

\section{CONCLUSION}

Landfill leachates contain some macromolecular organic substances that are resistant to biological degradation. With very low biodegradability ratios $\left(\mathrm{BOD}_{5} / \mathrm{COD}\right)$, usually lower than 0.21 , the complex matrixes show a recognized resistanc to conventional activated sludge systems. When sp ${ }^{\prime} e^{\prime}$ as a relatively brief pre-treatment, the sor catalyt process induces several modifications on the atrix, which results in a significant enh anent 0 its biodegradability. For this reasor the itegrated chemical-biological systems propos $d$ here 1 present a suitable solution for the satme. landfill leachate samples with an effic nt ediation of the relevant parameter ( $\mathrm{CO}^{-}$,

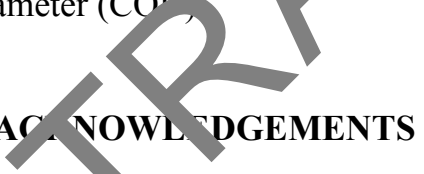

Auth $s$ would lik to thank the research office of Tehran Tniv isity of Medical Sciences.

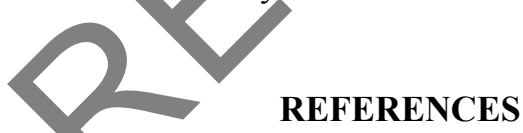

Abdul Aziz, H., Ling, T. J., Mokammel Haque, A. A., Umar, M. and Adlan, M. N., Leachate treatment by swim-bed bio fringe technology. Desalination, 276, No. 1-3, 278 (2011).

Acgdacg, O. N. and Sponza, D. T., Anaerobic/aerobic treatment of municipal landfill leachate in sequential two-stage up-flow anaerobic sludge blanket reactor
(UA N/comp tely stirred tank reactor (CSTR) syste s. r o ss Biochemistry, 40, 895 (2005).

Anglada, .., Urtiaga, A., Ortiz, I., Mantzavinos, D. and Dic, nadopoulos, E., Boron-doped diamond a odic treatment of landfill leachate: Evaluation o operating variables and formation of oxidation oy-products. Water Research, 45, No. 2, 828 (2011).

Atmaca, E., Treatment of landfill leachate by using electro-Fenton method, Journal of Hazardous Materials, 163, No. 1, 109 (2009).

Bae, B. U., Jung, E. S., Kim, Y. R. and Shin, H. S., Treatment of landfill leachate using activated sludge process and electron-beam radiation. Water Research, 33, No. 11, 2669 (1999).

Bashir, M. J. K., Abdul, Aziz, H., Yusoff, M. S., Aziz, S. Q. and Mohajeri, S., Stabilized sanitary landfill leachate treatment using anionic resin: treatment optimization by response surface methodology. Journal of Hazardous Materials, 182, No. 1-3, 115 (2010).

Ben Yahmed, A., Saidi, N., Trabelsi, I., Murano, F., Dhaifallah, T., Bousselmi, L. and Ghrabi, A., Microbial characterization during aerobic biological treatment of landfill leachate (Tunisia). Desalination, 246, No. 1-3, 378 (2009).

Bila, D. M., Montalvão, F., Silva, A. C. and Dezotti, M., Ozonation of a landfill leachate: evaluation of toxicity removal and biodegradability improvement. Journal of Hazardous Materials, 117, No. 2-3, 235 (2005).

Çeçen, F., Erdinçler, A. and Kiliç, E., Effect of powdered activated carbon addition on sludge 
dewaterability and substrate removal in landfill leachate treatment. Advances in Environmental Research, 7, No. 3, 707 (2003).

Chianese, A., Ranauro, R. and Verdone, N., Treatment of landfill leachate by reverse osmosis. Water Research, 33, No. 3, 647 (1999).

Chiang, L. C., Chang, J. E. and Wen, T. C., Indirect oxidation effect in electrochemical oxidation treatment of landfill leachate. Water Research, 29, No. 2, 671 (1995).

Cortez, S., Teixeira, P. T., Oliveira, R. and Mota, M., Evaluation of Fenton and ozone-based advanced oxidation processes as mature landfill leachate pretreatments. Journal of Environmental Management, 92, No. 3, 749 (2011).

Dehghani, M. H., Mahvi, A. H., Jahed, G. R. and Sheikhi, R., Investigation and evaluation of ultrasound reactor for reduction of fungi from sewage. Journal of Zhejiang University, Science, B., 8, No. 7, 493 (2007).

De Morais, J. L. and Zamora, P. P., Use of advanced oxidation processes to improve the biodegradability of mature landfill leachates. Journal of Hazardous Materials, 123, No. 1-3, 181 (2005).

Esplugas, S., Contreras, S. and Ollis, D. F., Engineering aspects of the integration of chemical and biological oxidation: sim a mechanistic models for the oxidation treat ent. Journal of Environmental Engineering, 1s0, (2004).

Guo, J. S., Abbas, A. A., Chen, Y. P., Liu, Z. P., rang, F. and Chen, P., Treatment of land all leachate using a combined stripping, Fenton, SB , and co gulation process. Journal of Hazardeıs Ma rials. 78 , No. 1-3, 699 (2010).

Kargi, F. and Pamukoglı-M. Removal of $\mathrm{Cu}(\mathrm{II})$ ions by biosorptio ont por dered waste sludge (PWS) prior to bir og al treatment in an activated $s^{1}$ dge vit: A statistical design approach. row ss Bioc..emistry, 38, No. 10, 1413 (2003)

Kargi, 5 and amukoglu, M. Y., Repeated fed-batch biolog a tr atment of pre-treated landfill lea hate $v$ powdered activated carbon addition. Er yn and Microbial Technology, 34, No. 5, 22 (2004).

Kettu, 2n, R. H., Hoilijoki, T. H. and Rintala, J. A., Anaerobic and sequential anaerobic-aerobic treatment of municipal landfill leachate at low temperatures. Bioresource Technology, 58, No. 1, 31(1996).

Koh, I. O., Hamacher, X. C., Hicke, K. and Thiermann, W., Leachate treatment by the combination of photochemical oxidation with biological process. Journal of Photochemistry and Photobiology A-Chemistry, 162, 261 (2004).

Kurniawan, T. A., Lo, W. H. and Gilbert, Y. S., Degradation of recalcitrant compounds from stabilized landfill leachate using a combination of ozone-GAC adsorption treatment. Journal of Hazardous Materials, 137, No. 1, 443 (2006)

Li, H. J., Gu, Y. Y. and Wen, Z. P., I cachate treatment using a demonstration a $d \mathrm{~d}$ r use biofilter. Journal of Environmental Sch 2 S, 22 No. 7, 1116 (2010).

Lim, P. E., Lim, S. P., Seng, C. E. an Noor, A. M., Treatment of landfill leach $1 \mathrm{~m}$ sequ nc $\mathrm{ng}$ batch reactor supplemented witl activate rice husk as adsorbent. Chemical ngi eering Journal, 159, No. 1-3, 123 (2010

Lim, Y. N., Sha da. M. O and Yin, C. Y., Treatment of landfill achate using palm shellactivated carb on column: Axial dispersion modeling ar atment profile. Chemical Engineering ournal, 146, No. 1, 86 (2009).

Mahvi, 1. Ap lication of ultrasonic technology for $\mathrm{ir}$ and wastewater treatment. Iranian Journal f Public Health, 38, No. 2, 1(2009).

Ma. vi, A. H., Maleki, A., Rezaee, R. and Safari, M., $\mathrm{R}$ duction of humic substances in water by splication of ultrasound waves and ultraviolet irradiation. Iranian Journal of Environmental Health Science and Engineering, 6, No. 4, 233 (2009).

Peixoto, A. L. C. and Izário Filho, H. J., Statistical evaluation of mature landfill leachate treatment by homogeneous catalytic ozonation. Brazilian Journal of Chemical Engineering, 27, No. 4, 531 (2010).

Peixoto, A. L. C., Silva, M. B. and Izário Filho, H. J., Leachate treatment process at a municipal stabilized landfill by catalytic ozonation: an exploratory study from Taguchi orthogonal array. Brazilian Journal of Chemical Engineering, 26, No. 3, 481 (2009).

Pi, K. W., Li, Z., Wan, D. J. and Gao, L. X., Pretreatment of municipal landfill leachate by a combined process. Process Safety and Environmental Protection, 87, No. 3, 191 (2009).

Pilli, S., Bhunia, P., Yan, S., LeBlanc, R. J., Tyagi, R. D. and Surampalli, R. Y., Ultrasonic pretreatment of sludge: A review. Ultrasonic Sonochemistry, 18, No. 1, 1 (2011).

Rafati, L., Mahvi, A. H., Asgari, A. R. and Hosseini, S. S. Removal of chromium (VI) from aqueous solutions using Lewatit FO36 nano ion exchange resin. International Journal of Environmental Science and Technology, 7, No. 1, 147 (2010). 
Robinson, H. D. and Maris, P. J., The treatment of leachates from domestic wastes in landfills - I: Aerobic biological treatment of a mediumstrength leachate. Water Research, 17, No. 11, 1537 (1983).

Schoeman, J. J., Evaluation of electro dialysis for the treatment of a hazardous leachate. Desalination, 224, No. 1-3, 178 (2008).

Schuk, W. W. and James, S. C., Treatment of landfill leachate at publicly owned treatment works. Waste Management and Research, 4, No. 3, 265 (1986).

Scullion, J., Winson, M. and Matthews, R., Inhibition and recovery in a fixed microbial film leachate treatment system subject to shock loading of copper and zinc. Water Research, 41, No. 18, 4129 (2007).

Sun, Y. J., Ma, G. P., Ye, X. Q., Kakuda, Y. K. and Meng, R. F., Stability of all-trans- $\beta$-carotene under ultrasound treatment in a model system:
Effects of different factors, kinetics and newly formed compounds. Ultrasonic Sonochemistry, 17, No. 4, 654 (2010).

Vilar, V. J. P., Rocha, E. M. R., Mota, F. S., Fonseca, A., Saraiva, I. and Boaventura, R. A. R., Treatment of a sanitary landfill leachate using combined solar photo-Fenton and biological immobilized biomass reactor at a pils scale. Water Research, 45, No. 8, 2647 (2010'

Wang, C. T., Chou, W. L. and Kuo, . M Removal of COD from laundry wastew. er oy electrocoagulation/electroflotatio. Journar of Hazardous Materials, 164, No., $81(\mathrm{~N} 0 \%$ ).

Zhao, G. H., Pang, Y. N., Liu L., Gao J. X. and Lu, B. Y., Highly effi ien and energy-saving sectional treatmer of din deachate with a synergistic syst $\mathrm{a}$ bioch nical treatment and electrochemical oxia tion on a boron-doped diamond elec ode. Journal of Hazardous Materials, 179 No. 1-3, 1078 (2010).

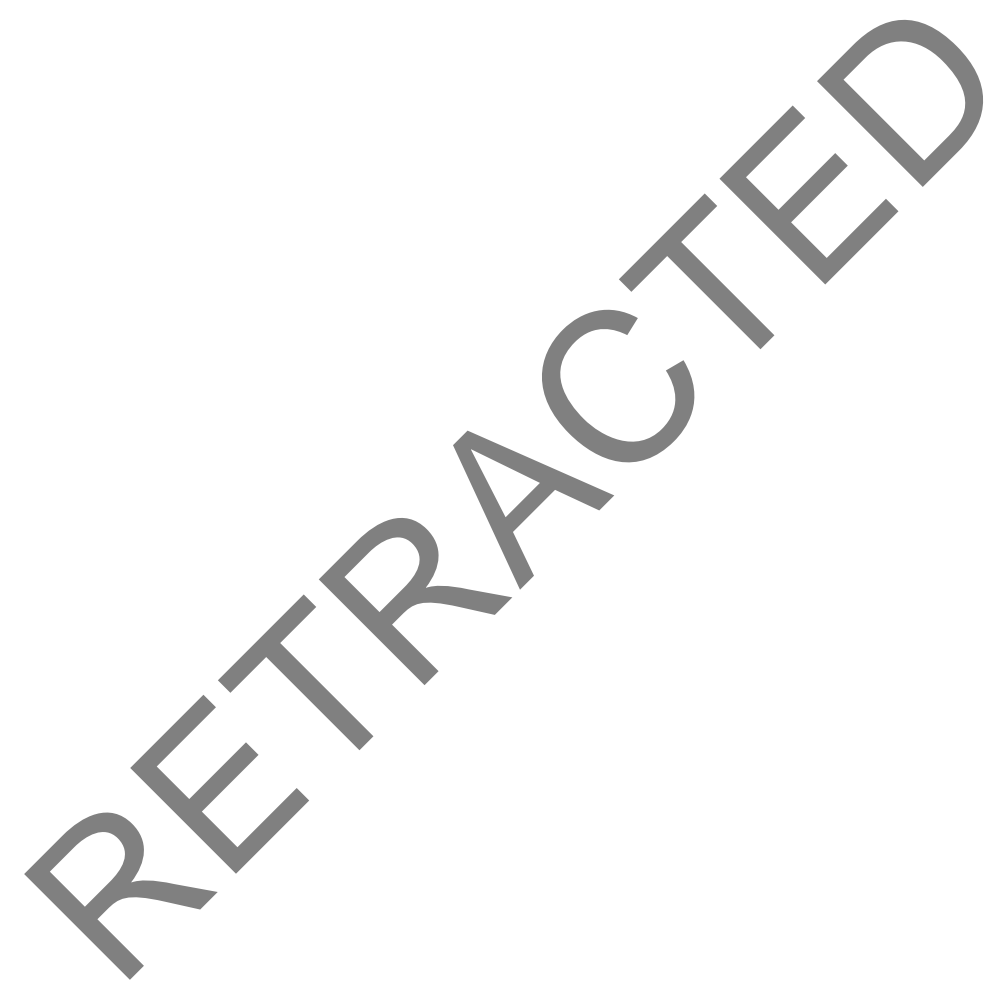

